\title{
Cocrystallization of Etodolac: Prediction of Cocrystallization, Synthesis, Solid State Characterization and In Vitro Drug Release
}

\author{
Dipak D. GADADE, Sanjay S. PEKAMWAR, Swaroop R. LAHOTI, Santosh D. PATNI, Mahesh C. SARODE
}

\begin{abstract}
The present investigation deals with determination of Hansen solubility parameters, synthesis and characterization of etodolac co-crystals with various coformers. Various coformers were screened under the study to prepare cocrystals of etodolac for improving its solubility and dissolution. The prepared cocrystals were characterized by saturation solubility study, Fourier transform infrared spectroscopy (FTIR), differential scanning calorimetry (DSC), powder X-ray diffraction (PXRD),
\end{abstract}

in vitro dissolution studies and stability study. The outcome of study show that the significant improvement in solubility with p-aminobenzoic acid, ferulic acid and salicylic acid. Etodolac:Salicylic acid cocrystal 1:1M were formulated as immediate release tablets. The results reveal that solubility and dissolution of etodolac was improved by cocrystallization and it possesses adequate pharmaceutical stability.

Keywords: Etodolac, Cocrystal, Solubility, Dissolution, Hansen Solubility Parameter
Dipak D. Gadade, Sanjay S. Pekamwar

School of Pharmacy, S.R.T.M. University, Vishnupuri, Nanded (India)- 431606

Swaroop R. Lahoti

Y.B. Chavan College of Pharmacy, Rauza Baug, Auranagabad (India)-431001

Santosh D. Patni, Mahesh C. Sarode

Shri Bhagwan College of Pharmacy, CIDCO-N6, Aurangabad (India)-431001

Corresponding Author:

Dipak D. Gadade

Email:deeps_cpn@yahoo.co.in

Phone No.+91-8275516317

Submitted / Gönderilme: 15.08.2016 Accepted / Kabul: 29.09.2016
Revised / Düzeltme: 27.09.2016

\section{INTRODUCTION}

Active pharmaceutical ingredients (API) with poor aqueous solubility are becoming more prevalent in the research and development portfolios of discovery focused pharmaceutical companies (1). Molecules of this type can encounter a number of challenges in pharmaceutical development and may subsequently lead to poor dissolution, poor systemic availability and consequent poor drug efficacy in patients, especially after oral administration. Developments in the field of pharmaceutical sciences have led to the establishment of a number of approaches for addressing the issues of low aqueous solubility. Crystal engineering approaches, which can potentially be applied to a wide range of crystalline materials, offering substitutive and potentially productive and beneficial method for improving the solubility, dissolution rate and subsequent bioavailability of poorly water soluble compounds for pharmaceutical and therapeutic applications (2). The ability to engineer materials with optimum dissolution attributes, whilst maintaining acceptable physicochemical stability provides a strong driver for the utilization of crystal engineering approaches to drug and drug intermediate design. The challenges of low aqueous solubility provide archetypal situation for the utilization of crystal engineering techniques for improving bioavailability, whilst also developing pharmaceutically stable, acceptable and robust dosage forms. This therefore considers the 
potential utility of crystal engineering as an approach for designing efficacious pharmaceutical dosage forms for poorly water soluble drugs. Pharmaceutical cocrystals provides an opportunity for the optimization of key physical and chemical properties of an API whilst retaining its molecular structure, and its physiological activity as there are no making or breaking of the API's covalent bonds. Significant physical, chemical and biological properties of an API such as its aqueous solubility, bioavailability, stability and processability features can be considerably improved upon cocrystallization, thus allowing for optimal drug formulation. Application of the fundamental concepts presented in this paper explains to examine the ability of Hansen solubility parameter to predict the formation of cocrystals systems and pharmaceutical properties of cocrystals, in particular solubility, dissolution, and stability (3). Several research reports of cocrystals show their ability to improve physicochemical including solubility, dissolution, stability, tabletability and pharmacokinetic characteristics especially bioavailability of active pharmaceutical ingredients (4-8). Cocrystal synthesis can work as green technique becoming avenue for pharmaceutical industry (9).

Etodolac, is $\quad 2$-[(1RS)-1,8-diethyl-1,3,4,9tetrahydropyrano[3,4-b]indol-1-yl] acetic acid, (fig.1), is a chiral nonsteroidal anti-inflammatory drug. It is used as analgesic and anti-inflammatory in the treatment of rheumatoid arthritis and osteoarthritis (10). It prohibits the synthesis of inflammatory peripheral prostaglandins by inhibition of the cycloxygenase- 2 enzyme. It produces less gastrointestinal toxicity compared to the other NSAIDs (11). Its major site of metabolism is liver where it is converted to inactive metabolites that are primarily eliminated via the renal route (10).

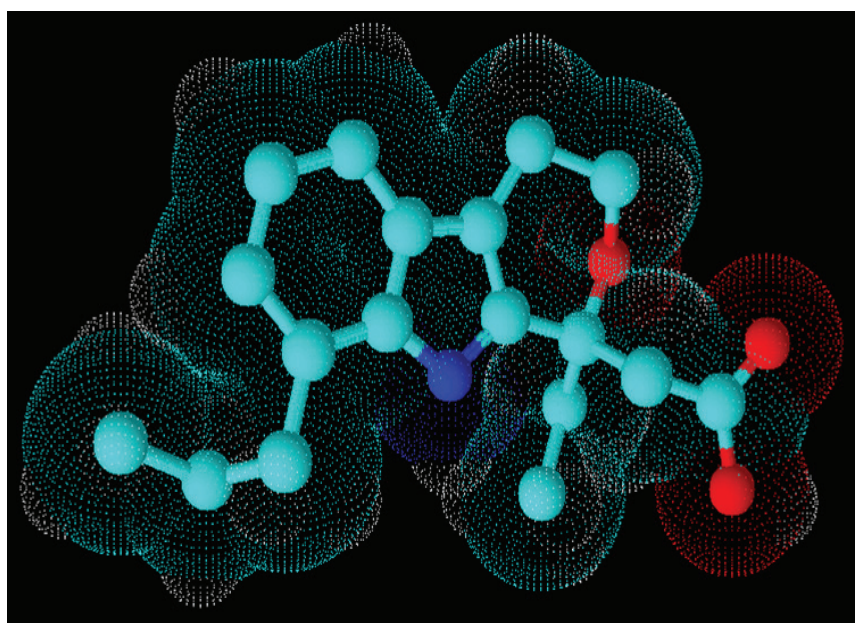

Figure 1. Chemical structure Etodolac etodolac was selected as it was associated with poor physicochemical characteristics including solubility (12), compressibility and flow properties which could be resolved with the help of crystal engineering i.e. cocrystallization.

The objective of the present study was to check the predictivity of Hansen solubility parameter to formation of multi-component cocrystals systems of etodolac. This could be useful to screen coformers which are having tendency to form cocrystals. In the present study we have screened various coformers based on predictions from Hansen solubility parameter prediction. The corystals with maximum solubility were selected and evaluated by differntial scanning calorimetry, Fourier transform infrared spectroscopy, and powder X-ray diffraction.

\section{MATERIALS AND METHODS}

\subsection{Materials}

S-Etodolac was provided by IPCA Lab., Mumbai as gift sample for study. All other chemicals and solvents used under study were of analytical grade and procured from Research Fine Lab, Mumbai.

\subsection{Methods}

\subsubsection{Prediction of Co-crystallization by Hansen Solubility Parameter (HSP)}

Solubility parameters for dry chemical components may be obtained by group contribution methods. We have combined Hoftyzer and Van Krevelen method and Fedors group contribution method. In Fedor's method, the chemical structure of etodolac was opened and subsequently the chemical structure was considered as open chain structure (13-14). The solubility parameter components may be calculated from group contributions (F) and molar volume $(\mathrm{Vm})$, using the following equations where $\delta \mathrm{d}$ represents dispersion forces energy, $\delta \mathrm{p}$ represents polar forces energy and $\delta \mathrm{h}$ represents hydrogen bonding energy (15). The representative calculations are given in Table 1.

$$
\begin{aligned}
& \delta \mathrm{d}=\left(\sum \mathrm{Fdi} / \Sigma \mathrm{Vm}\right) \text {-----------Eq.(1) } \\
& \delta \mathrm{p}=\left(\left[\sum \mathrm{Fpi}\right]^{0.5} / \Sigma \mathrm{Vm}\right) \text {-----------Eq.(2) } \\
& \delta \mathrm{h}=\left(\sum \text { Fhi } / \Sigma V m\right)^{0.5}---------------E q .(3)
\end{aligned}
$$


Table 1. Representative Calculation of Hansen Solubility Parameter of etodolac

\begin{tabular}{|c|c|c|c|c|c|}
\hline Group & Frequency & $\begin{array}{c}\text { Fdi } \\
\left(\mathrm{J}^{1 / 2} \mathrm{~cm}^{3 / 2} \mathrm{~mol}^{-1}\right)\end{array}$ & $\begin{array}{c}\text { Fpi } \\
\left(\mathrm{J}^{1 / 2} \mathrm{~cm}^{3 / 2} \mathrm{~mol}^{-1}\right)\end{array}$ & $\begin{array}{c}\text { Fhi } \\
(\mathrm{J} / \mathrm{mol})\end{array}$ & $\begin{array}{c}\mathrm{Vm}^{\mathrm{a}} \\
\left(\mathrm{cm}^{3} / \mathrm{mol}\right)\end{array}$ \\
\hline$-\mathrm{CH}_{3}$ & 2 & 840 & 0 & 0 & 67 \\
\hline$-\mathrm{CH}_{2}-$ & 5 & 1350 & 0 & 0 & 80.5 \\
\hline$-\mathrm{COOH}$ & 1 & 530 & 176400 & 10000 & 28.5 \\
\hline$-\mathrm{NH}-$ & 1 & 160 & 44100 & 3100 & 4.5 \\
\hline phenyl & 1 & 1270 & 12100 & 0 & 52.4 \\
\hline$>\mathrm{CH}-$ & 2 & 160 & 0 & 0 & -2.0 \\
\hline$-\mathrm{O}-$ & 1 & 100 & 160000 & 3000 & 3.8 \\
\hline$>\mathrm{C}<$ & 1 & 380 & 0 & 0 & 32 \\
\hline Ring closure & 2 & 0 & 0 & 0 & -4.4 \\
\hline $\begin{array}{l}\text { Conjugation in } \\
\text { ring }\end{array}$ & 2 & -70 & 0 & 0 & -19.2 \\
\hline$\Sigma$ & & 4720 & 392600 & 16100 & 243.1 \\
\hline
\end{tabular}

The resultant $\Delta \delta$ values of etodolac and selected coformers (Table 2) were compared to predict their solid state miscibility (16).

Table 2. Theoretical prediction of cocrystal formation by Van Kreevalen's method based on miscibility predictions.

\begin{tabular}{|c|c|c|c|c|c|c|}
\hline Compound & $\delta d$ & $\delta p$ & $\delta \mathrm{h}$ & $\delta \mathrm{t}$ & $\Delta \delta \mathrm{t}$ & REMARK \\
\hline Etodolac & 19.41 & 2.577 & 8.13 & 21.2 & --- & ----- \\
\hline Salicylic acid & 20.1 & 6.22 & 15.4 & 26.07 & 4.87 & MISCIBLE \\
\hline Benzoic acid & 19.62 & 4.35 & 10.01 & 22.45 & 1.25 & MISCIBLE \\
\hline Malonic acid & 18.19 & 8.13 & 16.54 & 25.89 & 4.69 & MISCIBLE \\
\hline Cinnamic acid & 18.6 & 3.42 & 8.88 & 20.89 & 0.31 & MISCIBLE \\
\hline L-tartaric ecid & 20.25 & 11.4 & 27.22 & 35.79 & 14.59 & IMMISCIBLE \\
\hline p-Aminobenzoic acid & 20.78 & 4.34 & 13.56 & 25.19 & 3.99 & MISCIBLE \\
\hline Hippuric acid & 20.41 & 6.92 & 10.72 & 24.07 & 2.87 & MISCIBLE \\
\hline Ferulic acid & 18.37 & 4.92 & 14.56 & 23.95 & 2.75 & MISCIBLE \\
\hline Maleic acid & 17.38 & 7.07 & 15.43 & 24.29 & 3.09 & MISCIBLE \\
\hline Glutaric acid & 17.76 & 5.64 & 13.78 & 23.17 & 1.92 & MISCIBLE \\
\hline Urea & 17.28 & 15.65 & 19.55 & 30.42 & 9.22 & IMMISCIBLE \\
\hline Ascorbic acid & 27 & 5.64 & 13.78 & 23.17 & 1.97 & MISCIBLE \\
\hline
\end{tabular}




\subsubsection{Preparation of cocrystals}

Etodolac was cocrystallized with various cocrystals formers (CCF) in the 1:1 Mol stoichiometric ratio using agate mortar and pestle by neat grinding method. The grinding was performed for 20 minutes for each batch (17). The flow properties of cocrystals were determined from angle of repose, Hausner's ratio and Carr's Index.

\subsubsection{Melting point determination}

The melting point of etodolac, CCFs and cocrystals were determined by Digital melting point apparatus (LABTRONICS Ltd) in triplicate.

\subsubsection{Differential Scanning Calorimetry (DSC)}

Thermal analysis of etodolac and cocrystals was performed by using a differential scanning calorimeter DSC-60A Shimadzu calorimeter. The samples were placed in aluminum pans, sealed hermetically and then these hermetically sealed aluminum pans were heated at a scanning rate of $20^{\circ} \mathrm{C} / \mathrm{min}$ from $50^{\circ}$ to $350^{\circ} \mathrm{C}$ under constant purging dry nitrogen flow $(20 \mathrm{~mL} / \mathrm{min})$. Empty aluminum pan was used as a reference.

\subsubsection{Fourier Transfer-Infrared Spectroscopy (FTIR)}

Shimadzu FTIR spectrometer Prestige 21 with DRS assembly was used in attenuated total reflectance (ATR) mode for collecting FT-IR spectra of samples. The spectrums were collected over the range of $4000-400 \mathrm{~cm}^{-1}$ in 45 scans, with a resolution of $5 \mathrm{~cm}^{-1}$ for each sample.

\subsubsection{Powder X-Ray diffraction Study (PXRD)}

In this study, a powder sample of etodolac and cocrystals was exposed to a beam of monochromatic $\mathrm{X}$-ray radiation using a Bruker D8 Discover, which was diffracted and recorded by an X-ray detector. The diffracted data was processed and an $\mathrm{X}$-ray diffraction pattern of powder was plotted.

\subsubsection{Solubility Study}

Saturation solubility studies etodolac and its cocrystals were performed in according to method reported by Higuchi and Connors (18). For saturation solubility, an excess quantity of cocrystals was added to vials containing $10 \mathrm{ml}$ of different solvent media. The vials were then subjected to rotary shaking for 24 hours. After shaking the solutions were filtered through Whatman filter paper No.41 and the filtrate was analyzed by UV spectrophotometer (SICAN 2310, Inkarp Instruments) at $280 \mathrm{~nm}$ with appropriate dilutions.

\subsubsection{Preparation of Immediate release tablets of etodolac Cocrystals}

Immediate release tablet formulation of etodolac cocrystals was prepared by wet granulation method by $2^{2}$ factorial experimental design. The disintegrant cross-carmellose sodium and binder poly vinyl pyrrolidone K30 (PVP-K30) were selected as independent variable. The formulae were as given in Table 3.

Table 3. Formulae for experimental factorial batches

\begin{tabular}{cc}
\hline Ingredients & Quantity \\
\hline Etodolac: Salicylic acid cocrystals & $435 \mathrm{mg}$ \\
Cross carmellose sodium & $5 \%-7 \%$ \\
PVP K30 & $2.5 \%-5 \%$ \\
MCC PH-101 & $\mathrm{q} . \mathrm{s}$ \\
Magnesium stearate & $1 \%$ \\
Total weight & $520 \mathrm{mg}$ \\
\hline
\end{tabular}

\subsubsection{Dissolution study of cocrystals and its formulation}

In vitro dissolution study was carried out using a USP type 2 apparatus (USP tablet Dissolution apparatus Veego VDA$6 \mathrm{DR}$ ) at a rotation speed of $100 \mathrm{rpm}$. Dissolution medium selected was phosphate buffer pH 6.8 (volume 1000ml, temperature $37^{\circ} \mathrm{C}$ ). After each sampling intervals, sample withdrawn was replaced by same amount of dissolution media kept at same temperature. The sample withdrawn was then immediately filtered and analyzed for sample content by UV spectrophotometer at $280 \mathrm{~nm}$ after suitable dilutions.

\subsubsection{Stability Study}

The immediate release tablets of etodolac-salicylic acid cocrystals were packed in aluminum foil and stored under the following environmental conditions for a period of One month as prescribed by $\mathrm{ICH}$ conditions at $5^{\circ} \mathrm{C} \pm 30^{\circ} \mathrm{C}$ and $25^{\circ} \pm 2{ }^{\circ} \mathrm{C} / \mathrm{RH} 60 \% \pm 5 \%$. The tablets were withdrawn at end of 15th and 30th day and evaluated for parameters including color change, assay (drug content), disintegration time, and dissolution study of formulation.

\section{RESULTS AND DISCUSSION}

The melting point of etodolac (Etd) and cocrystals were as reported in Table 4. It was observed that the melting point lower than the individual API or CCF indicating interaction between them. The Solubility of etodolac was significantly improved by cocrystal formation with salicylic acid, para amino benzoic acid and fumaric acid as compared other CCF under study. 
Table 4. Melting Point, Solubility of cocrystals prepared by Neat Grinding

\begin{tabular}{ccccc}
\hline $\begin{array}{c}\text { Batch } \\
\text { Code }\end{array}$ & Drug/Coformer & M.P of coformer $\left({ }^{\circ} \mathrm{C}\right)$ & $\begin{array}{c}\text { M.P. of cocrystal (by digital } \\
\text { melting apparatus) }\left({ }^{\circ} \mathbf{C}\right)\end{array}$ & Solubility $(\mathbf{m g} / \mathbf{L})$ \\
\hline F1 & ETODOLAC (Etd) & $145-148$ & --- & $676 \pm 3.0$ \\
NF1 & Etd Salicylic acid & $157-159$ & $116-118$ & $1566 \pm 5.33$ \\
NF2 & Etd Benzoic acid & 122 & $104-107$ & $155 \pm 2$ \\
NF3 & Etd Malonic acid & $134-136$ & $117-118$ & $49.2 \pm 3.26$ \\
NF4 & Etd Cinnamic acid & $132-134$ & $112-116$ & $233 \pm 2.66$ \\
NF5 & Etd tartaric Acid & $204-206$ & $202-206$ & $215 \pm 2.55$ \\
NF6 & Etd p-ABA & $185-188$ & $117-121$ & $3266 \pm 1.79$ \\
NF7 & Etd Hippuric acid & $187-190$ & $131-136$ & $204.9 \pm 2.90$ \\
NF8 & Etd Ferulic acid & 174 & $125-133$ & $2186 \pm 4.33$ \\
NF9 & Etd Maleic acid & $138-139$ & $90-11$ & $174.1 \pm 2.56$ \\
NF10 & Etd Glutaric acid & $94-97$ & $117-118$ & $134.1 \pm 4.56$ \\
NF11 & Etd Urea & 133 & sticky in nature & - \\
NF12 & Etd Ascorbic acid & $95-98$ & sticky in nature & - \\
\hline
\end{tabular}

The flow properties of etodolac and its cocrystals were as represented in Table 5. It reveals that there was marked improvement in flow properties of etodolac in cocrystals with salicylic acid as compared to the cocrystals with PABA and ferulic acid.

Table 5. Flow properties of etodolac and its cocrystals

\begin{tabular}{lllll}
\hline Parameters/Batch & Etodolac & NF1 & NF6 & NF8 \\
\hline $\begin{array}{l}\text { Bulk density } \\
\left(\mathrm{gm} / \mathrm{cm}^{3}\right)\end{array}$ & 0.315 & 0.311 & 0.222 & 0.323 \\
$\begin{array}{l}\text { Tapped density } \\
\left(\mathrm{gm} / \mathrm{cm}^{3}\right)\end{array}$ & 0.485 & 0.401 & 0.321 & 0.474 \\
$\begin{array}{l}\text { Compressibility } \\
\text { index }(\%)\end{array}$ & 35.05 & 22.40 & 30.84 & 31.85 \\
$\begin{array}{l}\text { Hausner's ratio } \\
\text { Angle of repose }\left(^{\circ}\right)\end{array}$ & 1.53 & 1.28 & 1.44 & 1.46 \\
\hline
\end{tabular}

The melting points of etodolac, NF1-cocrystal, N6-cocrystal and NF8-cocrystal were determined by DSC study and found to be $153.74^{\circ} \mathrm{C}, 119.44^{\circ} \mathrm{C}, 125.44^{\circ} \mathrm{C}, 127.28^{\circ} \mathrm{C}$ respectively (Fig.2 and 3). From the results of DSC study, the cocrystals formation (i.e. NF1, NF6, NF8 cocrystals) can be confirmed which show characteristic change in the melting behavior. Such peculiar change in melting behaviour confirms the formation of new phase suggesting cocrystal formation. In DSC thermograms the distinct endothermic peaks at temperature other than the melting peak of drug and CCFs and change in heat were observed indicating formation of cocrystal.

The FTIR spectra of API and cocrystals are shown in fig 2 and 4 . The carbonyl peak in the region $1680-1760 \mathrm{~cm}^{-1}$, -NH stretching region between $3300-3500 \mathrm{~cm}^{-1}$, ether $(-\mathrm{O}-)$ peak in the region between 1000 and $1300 \mathrm{~cm}^{-1}$ of etodolac was retained in all cocrystals spectrums. In most of the cocrystals, distinctive peaks for hydrogen bonding conformation were observed in FT-IR spectrum. The hydrogen bonding in cocrystals by FT-IR spectroscopy is detected by observing a decrease in intensity of $\mathrm{C}-\mathrm{O}-\mathrm{C}$ peak and appearance of low frequency broad C-O-C band. Broad features were observed in the region of $900-$ $1500 \mathrm{~cm}^{-1}$, indicating the occurrence of hydrogen bonding. A decrease in $\mathrm{N}-\mathrm{H}$ stretching frequency indicates that hydrogen is participating in hydrogen bonding. The extent of hydrogen bonding can be determined by extent of decrease in frequency and relative band broadening. The lowering of frequency is the function of degree and strength of hydrogen bonding. The significant changes observed in the region of amine $(\mathrm{N}-\mathrm{H})$ and carbonyl $(\mathrm{C}=\mathrm{O})$ stretching 
indicated formation of new hydrogen bonds.

The crystal structure of the etodolac and cocrystals (NF1, NF6, NF8) was confirmed by X-ray powder diffraction analysis (fig.2 and 5). The comparison of PXRD pattern of etodolac with its cocrystals reveals that there may be formation cocrystal as additional intense peaks were observed in cocrystals. It suggests development of new crystalline phases in cocrystals.

In a saturated solubility study of etodolac cocrystals it was observed that maximum improvement in solubility was observed with CCF in following order p-aminobenzoic acid $>$ ferulic acid $>$ salicylic acid (Table 4 ). It may be attributed to desirable noncovalent interaction between and API and CCF. Cocrystal with PABA shown discoloration with time while cocrystals with ferulic acid shown overlapping absorption in ultraviolet region with etodolac. Glutaric acid, urea and L-ascorbic acid formed undesirable sticky semisolid material during cocrystallization attempts with etodolac. While with other coformers under study solubility of etodolac was decreased.
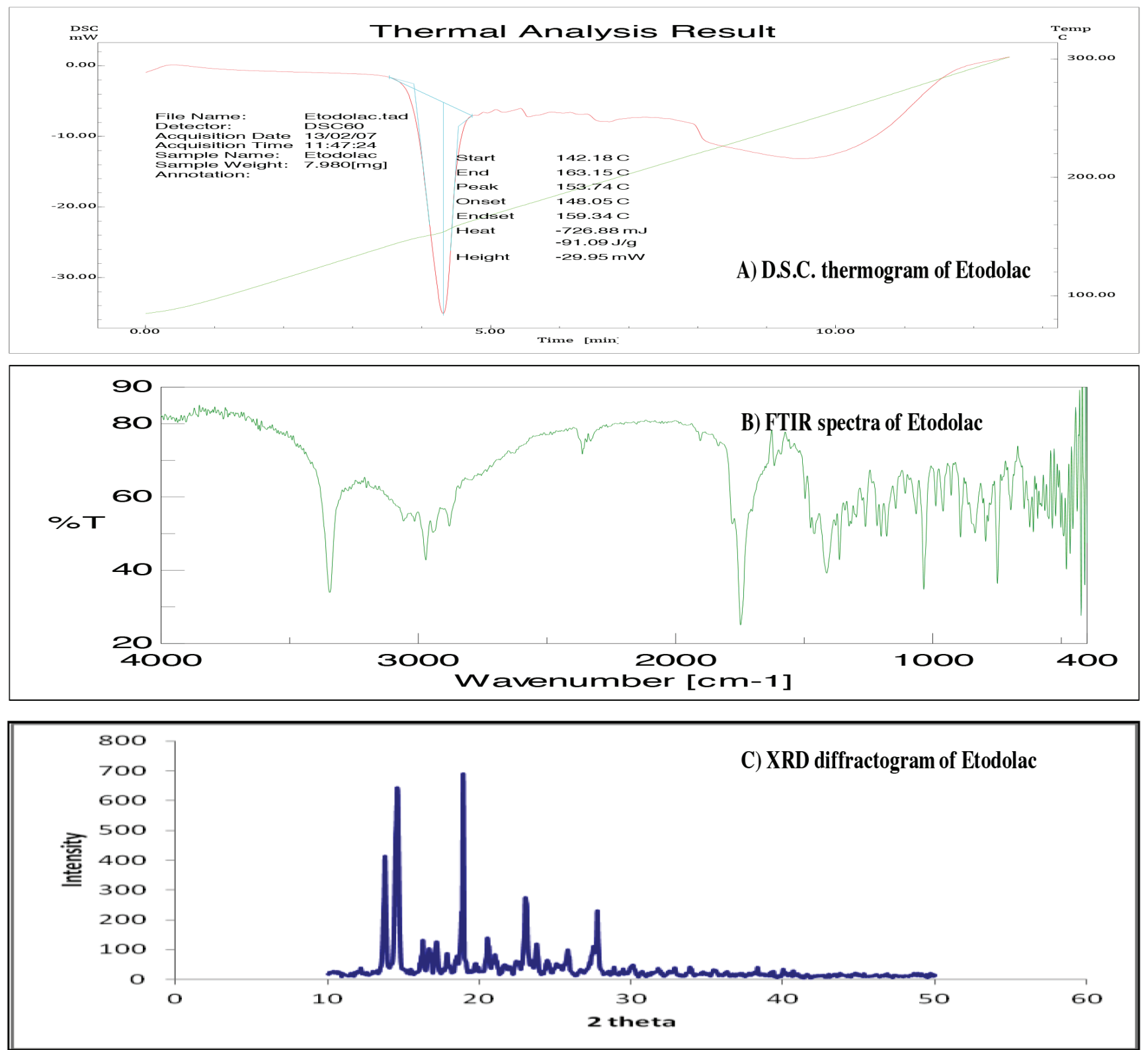

Figure 2. Thermal and spectroscopic study A) DSC thermogram of etodolac B) FTIR spectra of etodolac C) XRD diffractogram of etodolac 

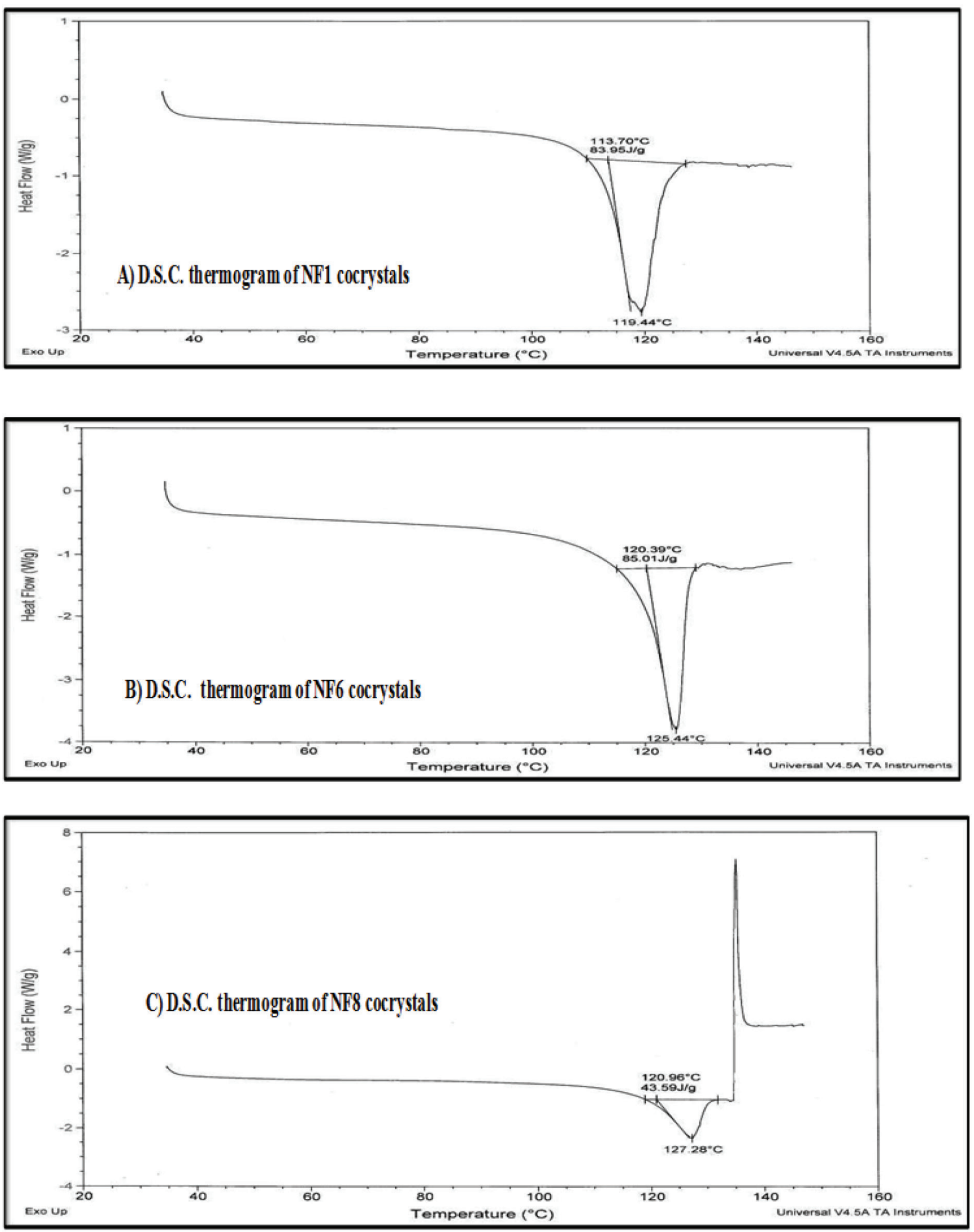

Figure 3. Thermal study (DSC Thermogram ) of cocrystals A)NF1 B)NF6 C) NF8 

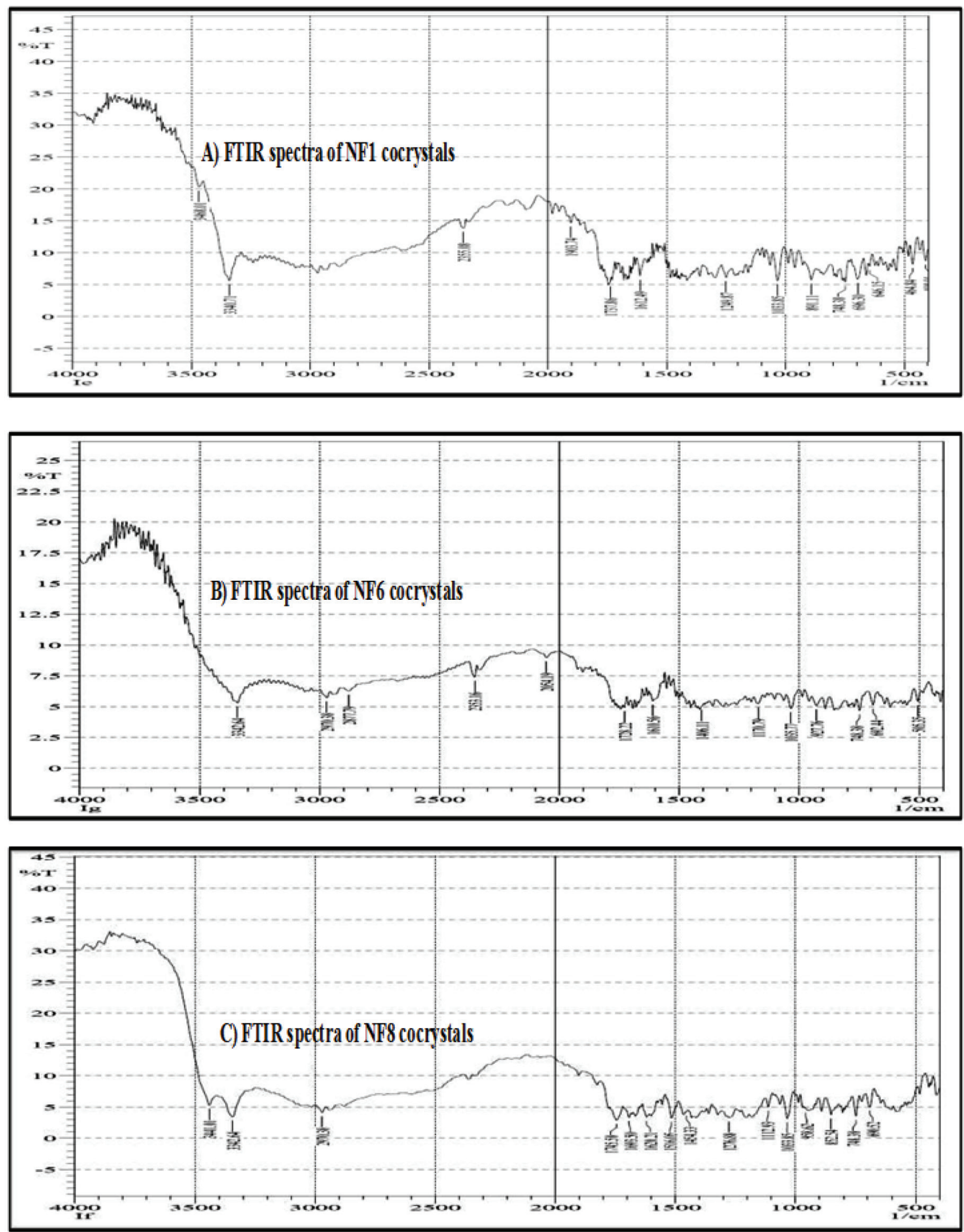

Figure 4. Spectroscopic study (FTIR Spectra) of cocrystal A) NF1 B) NF6 C) NF8 

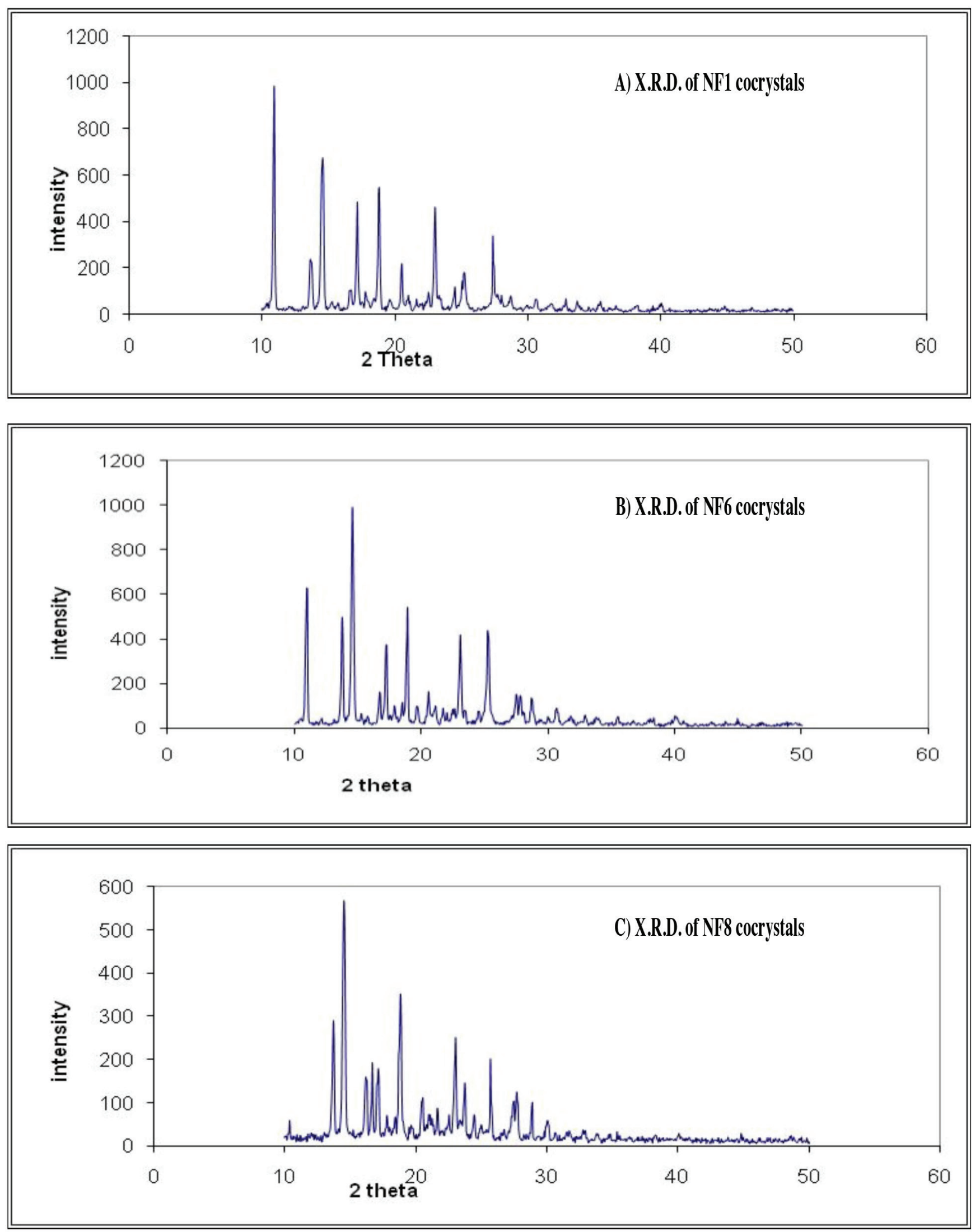

Figure 5. XRD study (diffractogram) of cocrystals A) NF1 B) NF6 C) NF8 


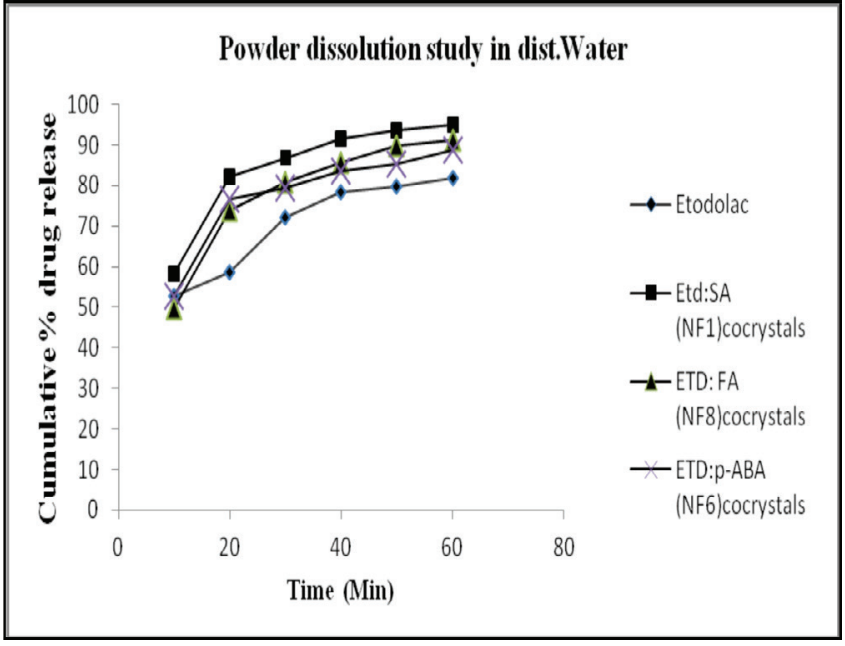

Figure 6. Powder dissolution study of API and cocrystals in dist. Water

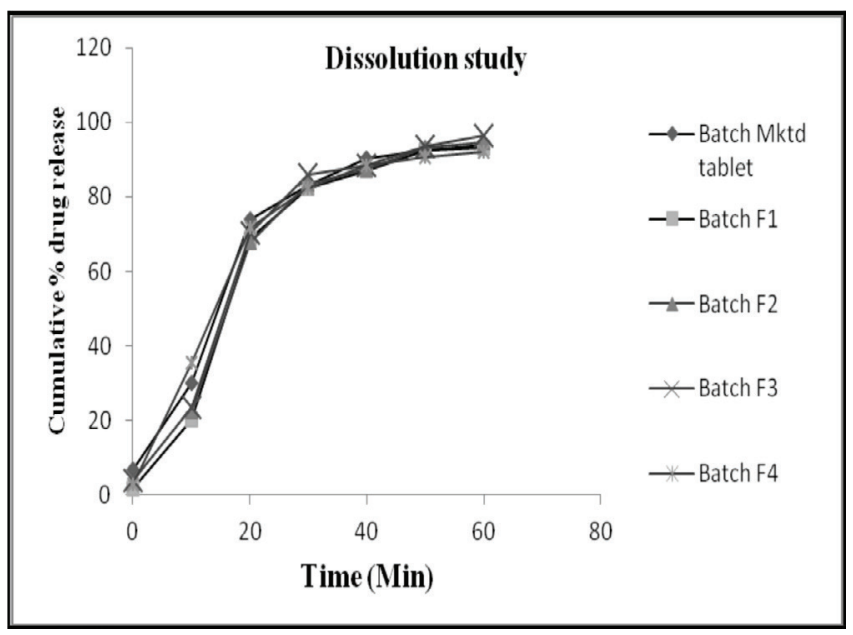

Figure 7. Dissolution study in phosphate buffer $\mathrm{pH} 6.8$
The results of powder dissolution study as shown in fig.6 reveal that dissolution of etodolac was improved by co-crystallization with salicylic acid, ferulic acid and p-aminobenzoic acid. The dissolution of the wet granulation immediate release tablet batches F1 to F4 and marketed tablet showed that almost overlapping dissolution profile (Fig. 7). The Batch -F3 batch was selected as optimized batch as comparatively highest dissolution was obtained as compared to other immediate release tablet batches and found that it was stable under stability study.

\section{CONCLUSION}

Calculations of Hansen solubility parameters were employed for theoretical predictions of cocrystals of etodolac based on miscibility of API and cocrystal former. It shows limited scope for prediction of cocrystal formation. The neat grinding method of Edotolac cocrystal synthesis resulted in improvement of solubility with PABA, ferulic acid and salicylic acid when they are used as cocrystal formers. It can serve as green method for improving physicochemical characteristics of etodolac.

\section{DECLARATION OF INTEREST}

All authors approve the final manuscript and declare that there are no conflicts of interests.

\section{FUNDING}

This research did not receive any specific grant from funding agencies in the public, commercial, or not-for-profit sectors.

\section{ACKNOWLEDGEMENT}

Authors are thankful to IPCA laboratories Ltd. Mumbai for providing gift sample of etodolac.
Etodolak'ın Ko-kristalizasyonu: Ko-kristalizasyon Tahmini, Ko-kristal Sentezi, Katı Faz Yapı Aydınlatma Çalışmaları ve In Vitro İlaç Salımı

\section{ÖZ}

$\mathrm{Bu}$ araştırma kapsamında, etodolak ko-kristallerinin sentezi ve farklı koformerlerin yapılarının aydınlatılması ile Hansen çözünürlük paratmetrelerinin tayini çalışılmıştır. Etodolak’ın çözünürlüğünün arttırılması ve dissolüsyon özelliğinin iyileştirilmesi amacıyla hazırlanan etodolak ko-kristallerinin farklı koformerleri izlenmiştir. Ko-Kristallerin yapısı; Fourier dönüşümlü infrared spektroskopisi (FTIR), diferansiyal taramalı kalorimetri (DSC) tayini, X-ışını kırınım (PXRD) tayini ile aydınlatılmış, ayrıca çözünürlük ve çözelti doygunluğu çalışmaları, in vitro dissolüsyon ve stabilite çalışmaları yapılmıştır. Çalışma sonucunda etodolak’ın, p-amino benzoik asit, ferrulik asit ve salisilik asit ile kokristalleri hazırlandığında çözünürlüğünün arttığı tespit edilmiştir. Etodolak:Salisilik ait 1:1M kokristalinin hızlı ilaç salımı için formüle edilen tablet içeriğinde kullanılması öngörülmüştür. Etodolak kokristallerinin yeterli farmasötik stabiliteye sahip oldukları ve etodolak’ın çözünürlük ve dissolüsyon özelliğini arttırdıkları sonucuna ulaşılmıştır.

Anahtar kelimeler: Etodolak, Ko-Kristal, Çözünürlük, Dissolüsyon, Hansen Çözünürlük Parametresi 


\section{REFERENCES}

1. Vijayaraj S, Omshanthi B, Anitha S, Sampathkumar KP. Synthesis and characterization of novel sulphoxide prodrug of famotidine. Indian J Pharm Educ 2014; 48: 35-44.

2. Blagden N, De Matas M, Gavan PT, York P. Crystal engineering of active pharmaceutical ingredients to improve solubility and dissolution rates. Adv Drug Deliver Rev 2007; 59: 617-30.

3. Yadav AV, Shete AS, Dabke AP, Kulkarni PV, Sakhare SS. Co-crystals: a novel approach to modify physicochemical properties of active pharmaceutical ingredients. Indian J Pharm Sci 2009; 71: 359-70.

4. Zhou Z, Li W, Sun WJ, Lu T, Tong HH, Sun CC, Zheng Y. Resveratrol cocrystals with enhanced solubility and tabletability. Int J Pharm 2016; 509: 391-9.

5. Sravani E, Mannava MC, Kaur D, Annapurna BR, Khan RA, Suresh K, Mittapalli S, Nangia A, Kumar BD. Preclinical bioavailability-bioequivalence and toxico-kinetic profile of stable succinc acid cocrystal of temozolomide. Current Sci 2015; 108: 1097-1106.

6. Childs SL, Kandi P, Lingireddy SR. Formulation of a danazol cocrystal with controlled supersaturation plays an essential role in improving bioavailability. Mol Pharmaceut 2013; 10: 3112-27.

7. Mulye SP, Jamadar SA, Karekar PS, Pore YV, Dhawale SC. Improvement in physicochemical properties of ezetimibe using a crystal engineering technique. Powder Tech 2012; 222: 131-8.

8. Goud NR, Gangavaram S, Suresh K, Pal S, Manjunatha SG, Nambiar S, Nangia A. Novel furosemide cocrystals and selection of high solubility drug forms. J Pharm Sci 2012; 101: 664-80.

9. Trask AV, Motherwell WS, Jones W. Solvent-drop grinding: green polymorph control of cocrystallisation. Chem Comm
2004; (7) :890-1.

10. Humber LG. Etodolac: The chemistry, pharmacology, metabolic disposition, and clinical profile of a novel antiinflammatory pyranocarboxylic acid. Med Res Rev 1987; 7: $1-28$.

11. Glaser K, Sung ML, O’Neill K, Hartman D, Carlson R, Kreft A, Kubrak D, Hsiao CL, Weichman B. Etodolac selectively inhibits human prostaglandin G/H synthase 2 (PGHS-2) versus human PGHS-1. Eur J Pharm 1995; 281: 107-11.

12. Naito Y, Matsuda H, Shimomura K, Kurihara K, Tochigi K, Tomono K. Measurement and correlation of solubilities of the poorly water-soluble pharmaceutical compound etodolac by addition of co-solvents. Fluid Phase Equilibr 2013; 357: 43-9.

13. Kitak T, Dumičić A, Planinšek $O$, Šibanc R, Srčič S. Determination of solubility parameters of ibuprofen and ibuprofen lysinate. Molecules 2015; 20: 21549-68.

14. Shewale S, Shete AS, Doijad RC, Kadam SS, Patil VA, Yadav AV. Formulation and solid state characterization of nicotinamidebased co-crystals of fenofibrate. Indian J Pharm Sci 2015; 77: 328-34.

15. Mohammad MA, Alhalaweh A, Velaga SP. Hansen solubility parameter as a tool to predict cocrystal formation. Int J Pharm 2011; 407: 63-71

16. Greenhalgh DJ, Williams AC, Timmins P, York P. Solubility parameters as predictors of miscibility in solid dispersions. J Pharm Sci 1999; 88: 1182-90.

17. Nguyen KL, Friščić T, Day GM, Gladden LF, Jones W. Terahertz time-domain spectroscopy and the quantitative monitoring of mechanochemical cocrystal formation. Nat Mater 2007; 6: 206-9.

18. Higuchi, KA Connors. Phase-solubility techniques. Adv Anal Chem Instrum 1965; 4: 117-212. 